\title{
Evaluation of Cytocompatibility of Thermopolymerized Denture Base Copolymer Containing a Novel Ring-opening Oxaspiro Comonomer
}

\author{
Ranganathan Ajay ${ }^{1}$, Vikraman Rakshagan ${ }^{2}$, Ramajayam Sasikala ${ }^{3}$, Jayaraman Raghunathan ${ }^{4}$, Vellingiri LalithaManohari ${ }^{5}$, \\ Kandasamy Baburajan ${ }^{6}$
}

\begin{abstract}
Aim and objective: To evaluate the cytocompatibility of a novel denture base copolymer processed with 3,9-dimethylene-1,5,7,11tetraoxaspiro[5,5] undecane (DMTOSU) comonomer using human keratinocytes (HKCs) and gingival fibroblasts (HGFs) by tetrazolium assay. Materials and methods: The specimens were grouped based on the composition of the resultant polymer and curing regimen employed. Nine disk-shaped specimens per group were polymerized by one of the following curing regimens. $\mathrm{G}_{\mathrm{CW}}$ : plain poly (methyl methacrylate) [P(MMA)] polymerized by short curing cycle in water-bath without DMTOSU; $\mathrm{G}_{\mathrm{TW}}: \mathrm{P}(\mathrm{MMA}-\mathrm{Co}-\mathrm{DMTOSU})^{\mathrm{W}}$ copolymer polymerized with 20 wt\% DMTOSU at $70^{\circ} \mathrm{C}$ for $2 \mathrm{~h}$ followed by short curing cycle in water bath; $\mathrm{G}_{\mathrm{TA}}: \mathrm{P}(\mathrm{MMA}-\mathrm{Co}-\mathrm{DMTOSU})^{\mathrm{A}}$ copolymer polymerized with $20 \mathrm{wt} \% \mathrm{DMTOSU}$ at $60^{\circ} \mathrm{C}$ for $45 \mathrm{~min}$ followed by $130^{\circ} \mathrm{C}$ for $20 \mathrm{~min}$ in an autoclave. Human keratinocytes and HGFs were employed to evaluate cell viability (CV\%) by elution method through tetrazolium assay.

Results: A statistically significant difference was obtained $(p<0.05)$ among the groups with both the cell types. The ascending order of cytocompatibility is $\mathrm{G}_{\mathrm{CW}}<\mathrm{G}_{\mathrm{TW}}<\mathrm{G}_{\mathrm{TA}}$ with the $\mathrm{CV} \%>70 \%$.

Conclusion: The novel P(MMA-Co-DMTOSU) denture copolymer is found to be more cytocompatible with HKC and HGF than the P(MMA).

Clinical significance:The novel P(MMA-Co-DMTOSU) denture base copolymer cytocompatible to HKCs and HGFs might bypass polymerization shrinkage and food accumulation at denture-tissue interface. Therefore, this copolymer is also anticipated to prevent oral malodor and stomatitis due to good tissue adaptability and dimensional accuracy.

Keywords: Cell viability, Copolymer, Cytocompatibility, Cytotoxicity, Ring-opening

World Journal of Dentistry (2022): 10.5005/jp-journals-10015-1901
\end{abstract}

\section{INTRODUCTION}

Thermopolymerized denture base resin (TP-DBR) owing to its incomplete degree of conversion (DC) yields methylmethacrylate (MMA) as unreacted residual monomer (URM). ${ }^{1}$ Each ingredient of the liquid monomer is a known contact/respiratory sensitizer/irritant. ${ }^{2,3}$ The toxicity of the monomers can be due to direct contact or leached out URM and its metabolites or in combination. Methylmethacrylate is known to get absorbed through the skin affecting the nerve myelination and conduction velocity in the fingers along with numbness. ${ }^{4}$ Sensory-motor peripheral neuropathy has been reported among dental technicians fabricating dental prostheses over 30 years. ${ }^{5,6}$ Methylmethacrylate also can be absorbed through gloves (latex, vinyl, nitrile, and butadiene-styrene) that can enhance the skin reactions by the trapped monomer. ${ }^{7}$

Contact dermatitis and respiratory hypersensitivity owing to monomeric vapors and trimmed particulates in the dental laboratories among the dental technicians or personnel have been reported. ${ }^{8,9}$ Also, during the practical handling/manipulation of DBR by the dental under/postgraduates, such health hazards could be discerned. ${ }^{10}$ Eczematous symptoms in the hands/skin owing to monomeric contact allergens of acrylic resin materials has been observed in 2 to $7 \%$ of dental practitioners. ${ }^{11,12}$ Formaldehyde $(\mathrm{HCHO})$ is an oxidative metabolite of the residual MMA and leaches out from the denture bases..$^{13,14}$ The allergic inflammatory oral mucosal reactions inflicted by the $\mathrm{HCHO}$ in denture users

\begin{abstract}
1,5 Department of Prosthodontics and Crown and Bridge, Vivekanandha Dental College for Women, Tiruchengode, Namakkal, Tamil Nadu, India ${ }^{2}$ Department of Prosthodontics and Crown and Bridge, Saveetha Dental College, Saveetha Institute of Medical and Technical Sciences, Chennai, Tamil Nadu, India

${ }^{3}$ Department of Prosthodontics and Crown and Bridge, Vinayaka Missions Sankarachariyar Dental College, Salem, Tamil Nadu, India

${ }^{4}$ Department of Prosthodontics and Crown and Bridge, Karpaga Vinayaga Institute of Dental Sciences, Chengalpattu, Tamil Nadu, India ${ }^{6}$ Department of Prosthodontics and Crown and Bridge, RVS Dental College and Hospital, Coimbatore, Tamil Nadu, India
\end{abstract}

Corresponding Author: Ranganathan Ajay, Department of Prosthodontics and Crown and Bridge, Vivekanandha Dental College for Women, Tiruchengode, Namakkal, Tamil Nadu, India, Phone: +91 8754120490, e-mail: jrangclassiq@gmail.com

How to cite this article: Ajay R, Rakshagan V, Sasikala R, et al. Evaluation of Cytocompatibility of Thermopolymerized Denture Base Copolymer Containing a Novel Ring-opening Oxaspiro Comonomer. World J Dent 2022;13(2):127-132.

Source of support: Nil

Conflict of interest: None

mandate to evaluate its release from the DBRs. ${ }^{15}$ Other inimical URM metabolites (methacrylic acid, benzoic acid, phenyl benzoate, and phenyl salicylate) and integrant that do not participate in 
polymerization (dibutyl phthalate) also get surfaced on the denture base owing to incomplete DC. ${ }^{16}$

The polymerization reaction of acrylic resins is seldom complete paving way to noxious URM release. Its concentration varies based on the polymerization techniques and conditions. ${ }^{17-20}$ The URM eventually leach into the aqueous ambient of oral cavity. ${ }^{21}$ Leached URM and metabolites are blameworthy for numerous in vitrocytotoxic reactions $s^{22,23}$ and in vivo allergic retaliations. ${ }^{24,25}$ Nevertheless, polymerization temperature and time determine the amount of URM responsible for various cytotoxic degrees. ${ }^{26,27}$ Commonly, elution/extract method was employed to evaluate the in vitro cytotoxicity on cell cultures by assessing enzymatic activity, which indirectly estimate the cytocompatibility of DBRs. ${ }^{28}$

Myriad denture base monomeric modifications have been executed. ${ }^{29}$ In our previous research, 3,9-dimethylene-1,5,7, 11-tetraoxaspiro[5,5] undecane (DMTOSU), a ring-opening anti-shrinking comonomer, was incorporated in the TP-DBR in an attempt to develop a new copolymer with no polymerization shrinkage. This comonomer successfully copolymerized yielding novel P(MMA-Co-DMTOSU) copolymer with superior DC than the neat poly(methyl methacrylate) $[P(M M A)] .{ }^{30,31}$ However, the cytocompatibility of this novel copolymer has not been reported yet in the dental literature. Hence, the present research aims to evaluate the cytocompatibility of the novel P(MMA-Co-DMTOSU) denture base copolymer employing human keratinocytes (HKCs) and human gingival fibroblasts (HGFs). The null hypothesis was that the P(MMA-Co-DMTOSU) denture base copolymer would not be cytotoxic to the cells.

\section{Materials and Methods}

The present cytocompatibility research was conducted at Puducherry Center for Biological Sciences, Puducherry. The chemicals used for DMTOSU synthesis and the chemical ingredients of TP-DBR were purchased from Aldrich Co. (Sigma-Aldrich, St. Louis, MO, USA) and used as acquired without further purifications (Table 1). The synthesis of DMTOSU and proportionating the integrants of TP-DBR were executed by following the procedures elucidated in our prevenient investigations. ${ }^{30,31}$ The polymerized specimen disks were categorized into three groups ( $n=9$ per group) based on the composition of the polymer/copolymer and curing regimen executed. The groups, their compositions, and curing regimens are tabulated in Table 2 . The mold spaces needed for the fabrication of specimen disks were achieved by following the modus operandi of a previous research. ${ }^{16}$ All the specimen disks $(22 \mathrm{~mm}$ diameter; $2.0 \pm 0.1 \mathrm{~mm}$ thick) were prepared by single investigator. The specimen disks were ultraviolet radiation treated for half an hour to prevent the contamination of the cell lines and culture medium. The cells employed in this research were human cervical keratinocytes (HeLa cell line; HKC) and HGF. Preparation of the eluates and 3-(4,5-dimethylthiazol-2-yl)-2,5-diphenyltetrazolium bromide (MTT) tetrazolium reduction assay was executed by strictly adhering ISO 10993-5 guidelines. Cells in culture medium without eluate treatment served as negative control (NC) or blank. Specimens' surface area $\left[2 \pi r(r+h) \mathrm{cm}^{2}\right]$ to elution medium's volume $\left(9 \mathrm{~mL}\right.$ ) ratio was $3 \mathrm{~cm}^{2} / \mathrm{mL}$ as recommended by ISO 10993-12 guidelines. A step-wise MTT assay procedure is elucidated in Table 3. Cell viability (CV\%) is directly proportional to amount of formazan formed, as detected by the optical density (OD) at $570 \mathrm{~nm}$ absorbance in a microplate reader (Alere AM2100). To quantify the $C V \%$, the equation, $C V \%=\left(\frac{O D 570 e}{O D 570 b}\right) \times 100$ was used, where OD 570 e and OD 570b represent the average of the obtained OD of eluates and blanks, respectively. CV\% $<70 \%$ of the blank indicates that the tested material is apparently cytotoxic.

Statistical analysis was performed by Statistical Package for the Social Sciences (SPSS) version 21.0 software program (SPSS Inc., Chicago, IL, USA). Test of normality by Kolmogorov-Smirnov test exhibited a statistically significant difference within the distribution of data among each group concerning HKC. Hence, the continuous data were furnished as median and quartiles [interquartile range (IQR)]. Kruskal-Wallis test and post hoc Dunn's test were employed to recognize differences in the $\mathrm{CV} \%$ among and between the groups. Concerning HGF, statistically insignificant difference within the distribution of data among each group was found by the normality test. The continuous data were furnished as mean and standard deviation (SD). One-way analysis of variance (ANOVA) and post hoc Bonferroni tests were used to ascertain the differences in the $\mathrm{CV} \%$ among and between the groups. $P<0.05$ was considered to be statistically significant.

\section{Results}

Concerning the $\mathrm{HKC}$, the median (IQR) $\mathrm{CV} \%$ of $\mathrm{G}_{\mathrm{CW}}, \mathrm{G}_{\mathrm{TW}}$, and $\mathrm{G}_{\mathrm{TA}}$ were $80.23(0.7), 86.37(0.21)$, and $92.10(1.1)$, respectively (Fig. 1). There exists a statistically significant difference among the groups. In the post hoc multiple comparisons, except for $\mathrm{NC}-\mathrm{G}_{\mathrm{CW}}, \mathrm{NC}-\mathrm{G}_{\mathrm{TW}}$, and $\mathrm{G}_{\mathrm{CW}}-\mathrm{G}_{\mathrm{TA}}$ comparisons, all other comparisons showed statistically insignificant differences $(p=0.406)$. The significant difference of $\mathrm{G}_{\mathrm{CW}}-\mathrm{G}_{\mathrm{TA}}$ and insignificant difference of $N C-\mathrm{G}_{\mathrm{TA}}$ comparisons were suggestive of cytocompatibility of $\mathrm{G}_{\mathrm{TA}}$. Concerning then $\mathrm{HGF}$, the mean (SD) CV\% of $G_{C W}, G_{T W}$, and $G_{T A}$ were $74.77(0.48)$, $88.88(0.44)$, and $89.66(0.84)$, respectively (Fig. 2). There is a significant difference

Table 1: Chemicals used in the research

\begin{tabular}{|c|c|c|c|}
\hline & & \multicolumn{2}{|c|}{ TP-DBR ingredients and function } \\
\hline \multicolumn{2}{|c|}{ Chemicals for DMTOSU synthesis } & Powder & Liquid \\
\hline \multicolumn{2}{|c|}{ 2-Methylene-1,3-propanediol } & $\begin{array}{l}P(M M A) \text { polymeric powder (molecular } \\
\text { weight: } 350 \times 10^{3} \mathrm{~g} / \mathrm{mol} \text { ) }\end{array}$ & $\begin{array}{l}\text { MMA (containing } \leq 30 \mathrm{ppm} \text { mequinol as inhibitor, } \\
99 \% \text { ) }\end{array}$ \\
\hline \multicolumn{2}{|c|}{ Tetraethyl orthocarbonate } & Dibenzoyl peroxide (DBPO) as initiator & $\begin{array}{l}\text { Tricyclodecane dimethanol diacrylate (TCDDMDA) } \\
\text { as cross-linking agent }\end{array}$ \\
\hline \multirow{2}{*}{\multicolumn{2}{|c|}{$\begin{array}{l}\text { 1,3-dichloro-1,1,3,3-tetrabutyl distan- } \\
\text { noxane (Otera's catalyst) }\end{array}$}} & & $\begin{array}{l}\text { Boron trifluoride diethyl etherate (BFDE) as initiator } \\
\text { in cationic ring-opening polymerization }\end{array}$ \\
\hline & & & Di-tert-butyl peroxide (DTBP) as initiator \\
\hline 128 & \multicolumn{2}{|c|}{ World Journal of Dentistry, Volume 13 Issue 2 (March-April 2022) } & \\
\hline
\end{tabular}


Table 2: Groups, composition, and curing regimen

\begin{tabular}{|c|c|c|}
\hline Group & Composition & Curing regimen \\
\hline $\mathrm{G}_{\mathrm{CW}}$ & $\begin{array}{l}\text { Powder ( } 75 \text { wt.\%): P(MMA) pre- } \\
\text { polymeric powder with } 2 \text { wt.\% } \\
\text { DBPO. Liquid ( } 25 \text { wt.\%): MMA + } \\
\text { 10\% TCDDMDA. }\end{array}$ & $\begin{array}{l}\text { Thermo-polymerized at } \\
74^{\circ} \mathrm{C} \text { for } 2 \mathrm{~h} \text { followed by } \\
100^{\circ} \mathrm{C} \text { for } 1 \mathrm{~h} \text { in water bath } \\
\text { (short polymerization } \\
\text { cycle). Resultant polymer: } \\
\text { P(MMA). }\end{array}$ \\
\hline $\mathrm{G}_{\mathrm{TW}}$ & $\begin{array}{l}\text { Powder ( } 60 \text { wt.\%): P(MMA) } \\
\text { polymeric powder with } 2 \text { wt.\% } \\
\text { DBPO. Liquid ( } 20 \text { wt.\%): MMA } \\
+10 \% \text { TCDDMDA with } 4 \text { mol\% } \\
\text { BFDE. To the powder-liquid } \\
\text { mix, } 20 \text { wt.\% DMTOSU was } \\
\text { added. }\end{array}$ & $\begin{array}{l}\text { Thermo-polymerized at } \\
70^{\circ} \mathrm{C} \text { for } 2 \mathrm{~h} \text { followed by } \\
\text { short polymerization cycle } \\
\text { in water bath. } \\
\text { Resultant copolymer: } \\
\text { P(MMA-Co-DMTOSU) }{ }^{\mathrm{w}} \text {. }\end{array}$ \\
\hline $\mathrm{G}_{\mathrm{TA}}$ & $\begin{array}{l}\text { Powder ( } 60 \text { wt.\%): P(MMA) } \\
\text { polymeric powder with } 2 \text { wt.\% } \\
\text { DBPO. Liquid ( } 20 \text { wt.\%): MMA } \\
+10 \% \text { TCDDMDA with } 4 \text { mol\% } \\
\text { BFDE and } 4 \text { mol\% DTBP. To the } \\
\text { powder-liquid mix, } 20 \text { wt.\% } \\
\text { DMTOSU was added. }\end{array}$ & $\begin{array}{l}\text { Thermo-polymerized at } \\
60^{\circ} \mathrm{C} \text { for } 45 \text { min followed } \\
\text { by } 130^{\circ} \mathrm{C} \text { for } 20 \text { min in } \\
\text { digital vertical autoclave. } \\
\text { Resultant copolymer: } \\
\text { P(MMA-Co-DMTOSU) }\end{array}$ \\
\hline
\end{tabular}

Table 3: MTT assay-step-wise procedure

\begin{tabular}{|c|c|}
\hline $\begin{array}{l}\text { Time } \\
{[\mathrm{h}]}\end{array}$ & Procedure \\
\hline $00: 00$ & $\begin{array}{l}\text { HKC and HGF were plated separately in } 48 \text { well plates at } \\
\text { a concentration of } 2 \times 10^{4} \text { cells/well in DMEM (Dulbecco's } \\
\text { modified Eagle medium) culture medium with antibiotic } \\
\text { solution and } 10 \% \text { fetal bovine serum and incubated at } \\
37^{\circ} \mathrm{C} \text { in } 5 \% \mathrm{CO}_{2} \text { atmosphere for } 24 \mathrm{~h} \text {. Three specimens } \\
\text { were suspended in } 9 \mathrm{~mL} \text { of culture medium and incubated } \\
\text { as above. The resultant medium was used as eluates for } \\
\text { treating cells. }\end{array}$ \\
\hline $24: 00$ & $\begin{array}{l}\text { Once the monolayer of the cells was achieved, the culture } \\
\text { medium was aspirated and the cells were rinsed with PBS } \\
\text { (phosphate-buffered saline). } 200 \mu \mathrm{L} \text { of eluates were added } \\
\text { to cells and the plates were incubated as mentioned } \\
\text { above. Cells with no eluate treatment served as NC. NC } \\
\text { served as blank. }\end{array}$ \\
\hline $48: 00$ & $\begin{array}{l}\text { The eluates were aspirated and the cells were washed with } \\
\text { PBS. } 100 \mu \mathrm{L} \text { of MTT solution }(0.5 \mathrm{mg} / \mathrm{mL}) \text { was incorporated } \\
\text { to each well and incubated as above for } 4 \text { hours in a dark } \\
\text { environment. }\end{array}$ \\
\hline $51: 00$ & $\begin{array}{l}\text { The MTT solution was discarded from the cells and washed } \\
\text { with } 200 \mu \mathrm{L} \text { of PBS. The reduced violet-blue formazan } \\
\text { crystals were dissolved with } 100 \mu \mathrm{L} \text { of di-methyl sulfoxide } \\
\text { and swayed for } 30 \mathrm{~min} \text {. }\end{array}$ \\
\hline $51: 30$ & $\begin{array}{l}\text { Subsequently, the culture plates were transferred to a } \\
\text { microplate reader and the color intensity was measured at } \\
570 \mathrm{~nm} \text { absorbance. }\end{array}$ \\
\hline
\end{tabular}

The experiment was performed thrice in triplicate for reproducibility ${ }^{6}$

among and between the groups $(p<0.05)$. Concerning both $\mathrm{HKC}$ and $\mathrm{HGF}, \mathrm{G}_{\mathrm{CW}}$ possessed greater cytotoxicity than the other groups and $\mathrm{G}_{\mathrm{TA}}$ exhibited the least cytotoxicity. The ascending order of cytocompatibility is $\mathrm{G}_{\mathrm{CW}}<\mathrm{G}_{\mathrm{TW}}<\mathrm{G}_{\mathrm{TA}}$ with the $\mathrm{CV} \%$ $>70 \%$. Hence, the novel copolymer P(MMA-Co-DMTOSU) is cytocompatible with both HKC and HGF.

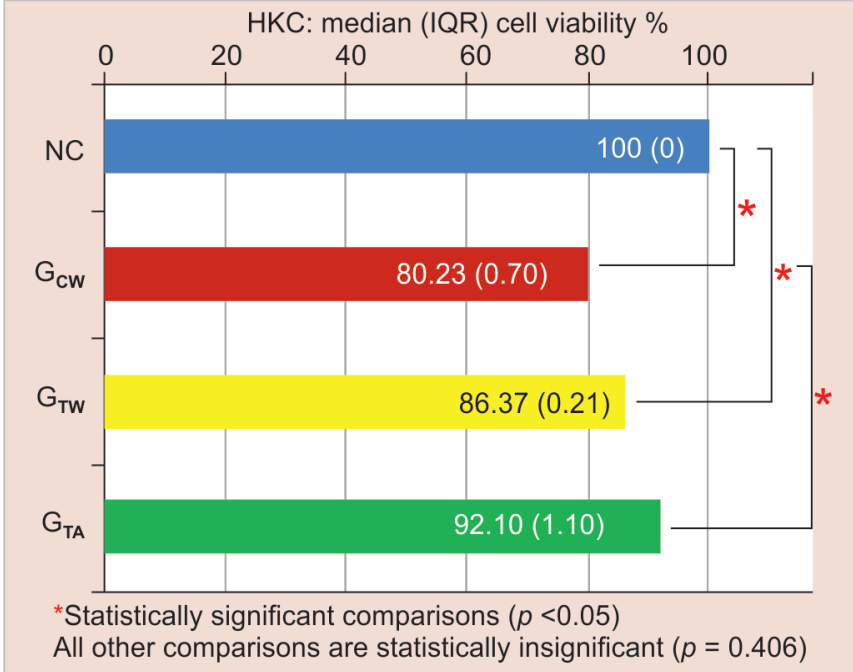

Fig. 1: Human keratinocytes and cell viability percentage

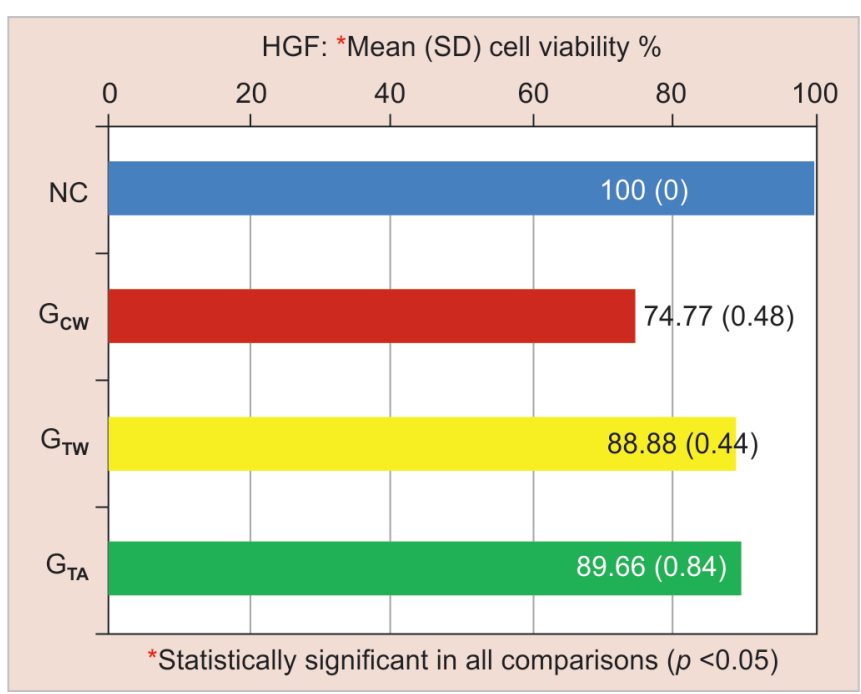

Fig. 2: Human gingival fibroblasts and cell viability percentage

\section{Discussion}

In this present research, the TP-DBR was modified by adding 20 wt.\% DMTOSU to the powder-liquid mixture. This modification yielded novel P(MMA-Co-DMTOSU) ${ }^{\mathrm{W}}$ copolymer of $\mathrm{G}_{\mathrm{TW}}$ and $\mathrm{P}(\mathrm{MMA}-\mathrm{Co}-\mathrm{DMTOSU})^{\mathrm{A}}$ copolymer of $\mathrm{G}_{\mathrm{TA}}$. The resultant copolymers were subjected to in vitro cytotoxicity test by MTT assay employing HKCs and HGFs. Intriguingly, both $\mathrm{G}_{\mathrm{TW}}$ and $\mathrm{G}_{\mathrm{TA}}$ were cytocompatible with $\mathrm{CV} \%$ greater than $85 \%$. Likewise, modifying DBR with $\mathrm{N}$-acetyl cysteine (NAC) ${ }^{32}$ and silver nanoparticles ${ }^{33}$ did not affect the mammalian CV\%. Ajay et al. ${ }^{16}$ concluded that modifying the DBR polymer with a cycloaliphatic comonomer resulted in higher OD values and CV\% than NC. Addition of carbon-graphite fibers ${ }^{34}$ and conglomerates of MMA-elemental iodine ${ }^{35}$ in the DBR were found to be noncytotoxic. Cochis et al. ${ }^{36}$ concluded that inclusion of biosurfactants in prosthetic materials to prohibit biofilm formation were cytocompatible. Conversely, methacryloyloxyundecyl pyridinium bromide (MUPB) ${ }^{37}$ and polyoxymethylene ${ }^{38}$ in the DBR jeopardized the CV\%. An increased CV\% can be inferred as an increased number of viable cells owing to the increased reduction of soluble MTT into 
insoluble violet-blue formazan and vice versa. Hence, from the above context, it is apparent that the type of comonomer added determines the cytocompatibility of the DBR.

Denture base resins educe varying degrees of in vitro cytotoxicity and in vivo hypersensitive reactions that are attributable to the URM $(C=C$; carbon-carbon double bond) owing to incomplete DC. Furthermore, curing regimen and postcure thermal treatments influence the DC and URM release. ${ }^{17,31}$ In the current research, though $\mathrm{G}_{\mathrm{CW}}[\mathrm{P}(\mathrm{MMA})]$ exhibited cytocompatibility with both HKC and HGF, CV\% were lesser than the $\mathrm{G}_{T W}$ and $\mathrm{G}_{T A}$. This can be ascribed to the URM leach-out from the polymerized specimens. The URM ensued due to the incomplete polymerization or low DC. In our previous research, $\mathrm{P}(\mathrm{MMA})$ manifested lower DC than the P(MMA-Co-DMTOSU) ${ }^{\mathrm{A}} .{ }^{31}$ This result concerning GCW is congruent with the previous studies, where DBR polymer without cycloaliphatic comonomer demonstrated lesser DC and greater cytotoxicity than the copolymer containing the same comonomer. ${ }^{16,39}$

The cytotoxicity of $\mathrm{G}_{T W}$ was in-between the $\mathrm{G}_{C W}$ and $\mathrm{G}_{T A}$. The higher $C V \%$ of $\mathrm{G}_{\mathrm{TW}}$ than $\mathrm{G}_{\mathrm{CW}}$ can be ascribed to the curing regimen employed and the composition. The polymerization of GTW exploited dual hybrid initiations videlicet free radical (Ró) initiation [Dibenzoyl peroxide (DBPO) and Di-tert-butyl peroxide (DTBP)] and cationic $\left(\mathrm{H}^{+}\right)$initiation Boron trifluoride diethyl etherate (BFDE). The context of using $\mathrm{H}^{+}$initiation was to achieve ring opening of the DMTOSU comonomer and expansion. Bailey and Endo ${ }^{40}$ reported $4.3 \%$ expansion of DMTOSU while processing with $1 \mathrm{~mol} \% \mathrm{BFDE}$ at $37^{\circ} \mathrm{C}$ and $7 \%$ expansion at $70^{\circ} \mathrm{C}$. Therefore, in $\mathrm{G}_{\mathrm{TW}}$, the initial thermopolymerizing temperatures were held at $70^{\circ} \mathrm{C}$ for cationic initiation by BFDE. Thus, $\mathrm{P}(\mathrm{MMA}-\mathrm{Co}-$ DMTOSU) ${ }^{\mathrm{W}}$ had a ring-opened poly (ether carbonate) (PEC) chain containing pendant $\mathrm{C}=\mathrm{C}$ bond (unsaturated carbon-carbon bond) of methylene moiety resulting in lower $D C$ than the $P(M M A)$ in our antecedent study. ${ }^{31}$ This may be misinterpreted as high URM content that would decrease the CV\% of P(MMA-Co-DMTOSU) $W$ copolymer. On the contrary, in the present research, $\mathrm{P}$ (MMA-Co-DMTOSU)W possessed greater CV\% than the P(MMA). This may be because the unsaturated bond in the ring-opened PEC chain is noncytotoxic. However, the unsaturated bond in the MMA polymeric chain is well-known for its cytotoxicity.

The $C V \%$ of the $G_{T A}$ was greater than the $G_{C W}$ and $G_{T W}$, which can be attributable to the DC. In our previous research, P(MMA-Co-DMTOSU) ${ }^{A}$ possessed the highest DC owing to hybrid dual Ro $-\mathrm{H}^{+}$initiations. ${ }^{31}$ Higher the DC, lesser the URM, and higher the $\mathrm{CV} \%$. Nonetheless, $\mathrm{G}_{\mathrm{TA}}$ was polymerized in the autoclave resulting in highly cross-linked $\mathrm{P}(\mathrm{MMA}-\mathrm{Co}-\mathrm{DMTOSU})^{\mathrm{A}}$. The crosslinking site was the pendant $C=C$ site of the ring-opened PEC chain which led to high DC, negligible URM, and resulted in cytocompatible crosslinked denture copolymer. Hence, DMTOSU can act as a crosslinker when cured in the autoclave. Therefore, there is an inverse relation between DC and URM content/cytotoxicity. Also, the URM content and cytotoxicity are directly proportional.

The type and crosslinker's concentration also determine the cytotoxicity of the DBR. The commonly employed crosslinker is ethylene glycol dimethacrylate (EGDMA). Horie et al. ${ }^{41}$ reported a decreased DC with increased EGDMA concentration. Moharram et al. ${ }^{42}$ found that incorporating 12 or $17 \%$ of triethylene glycol dimethacrylate (TEGDMA) or tetrahydrofurfuryl methacrylate (THFMA) crosslinkers to the DBR decreased the URM content. Viljanen et al. ${ }^{43}$ concluded that addition of dendritic cross-linker (dendrimer) to DBR increased the DC and lowered the URM. Hence, in this present study, the incorporation of 20 wt.\% of DMTOSU in TP-DBR produced P(MMA-Co-DMTOSU) ${ }^{\mathrm{W}}$ and $\mathrm{P}\left(\mathrm{MMA}\right.$-Co-DMTOSU) ${ }^{\mathrm{A}}$ copolymers with higher CV\% than the P(MMA). Therefore, the null hypothesis was accepted.

Denture base resin contacts disparate oral cells with conspicuous functions. Fibroblasts are the dominant cells in the oral mucosal connective tissue. However, the first layer of contact occurs on the keratin layer and keratinocytes. HKC was selected due to the potential direct apposition of the DBR on to the keratinocytes. Since DBR remains in close approximation with keratinized/nonkeratinized epithelium, leached eluates from the denture less than $100 \mathrm{kDa}$ can percolate through the epithelium to reach underlying connective tissue/fibroblasts. ${ }^{44}$ Various in vitro cytotoxicity tests have been performed with mouse fibroblasts. ${ }^{28}$ Although mouse fibroblasts are mammalian in origin, use of human cells would be appropriate to simulate and correlate in vivo response more accurately. Human fibroblasts are exposed after epithelial ulcerations caused by traumatic dentures and exhibit amplified clinical relevance when compared to other mammalian fibroblasts. Studies with human cells that simulate some clinical perspectives are scarce in the dental literature. Hence, in the current research HKC and HGF were employed which is in accordance to Japanese guidelines to evaluate the biological effects of dental materials. ${ }^{45}$

Predominantly, oral tissues are in contact with resinous polymerized dental biomaterials directly and indirectly. Oral mucosa, dental pulp, periodontal ligament cells, bone, and blood cells come into direct tissue-material contact. Indirect polymeric material-tissue contact occurs through the exudates leach out from the DBR. ${ }^{46}$ In the present research, eluates of the test specimens were acquired promptly following specimens' polymerization. It is mandatory to test the specimens swiftly after curing to prevent the deprivation of noxious URM leached from the specimens at an early stage and avoid false-negative results.

The results of the present research may not be projected on in vivo scenario. However, with negating factors extinguished, the in vitro studies are frequently considered as relevant corroboration in evaluating the cytocompatibility of DBRs. ${ }^{47}$ The DBRs experience drastic mechanical and thermal changes in the oral environments while in service. Simulating the in vivo oral aqueous ambience is the prime limitation to be considered while extrapolating the outcomes of in vitro studies to actual clinical conditions. ${ }^{48}$ Nevertheless, evaluating the cytotoxicity of DBRs by MTT assay is comparatively easy to execute, reproducible, reliable, and inexpensive. Therefore, it warrants in vivo studies withal to recognize the tissue changes caused by the P(MMA-Co-DMTOSU) copolymer.

\section{Conclusion}

Adhering the experimental etiquette and considering the limitations, it can be concluded that the novel P(MMA-Co-DMTOSU) copolymer is cytocompatible with HKC and HGF.

\section{References}

1. Keyf FA, Keyf Al. Harmful effects of methylmethacrylate and formaldehyde from acrylic resin denture basematerials. Saudi Dent J 1998;10(1):25-28. Corpus ID: 137858628.

2. Kanerva L, Henriks-Eckerman ML, et al. Occupational allergic contact dermatitis and composition of acrylates in dentin bonding systems. J Eur Acad Dermatol Venerol 1994;3:157-168. DOI: 10.1111/j.1468-3083.1994.tb00091.x 
3. Enoch SJ, Roberts DW, Cronin MTD. Electrophilic reaction chemistry of low molecular weight respiratory sensitizers. Chem Res Toxicol 2009;22:1447-1453. DOI: 10.1021/tx9001463

4. Bohling HG, Borchard U, Drouin H. Monomeric methylmethacrylate (MMA) acts on the desheathed myelinated nerve and on the node of Ranvier. Arch Toxicol 1977;38(4):307-314. DOI: 10.1007/BF00352035

5. Seppalainen AM, Rajaniemi R. Local neurotoxicity of methyl methacrylate among dental technicians. Am J Ind Med 1984; 5(6): 471-477. DOI: 10.1002/ajim.4700050606

6. Donaghy M, Rushworth G, Jacobs JM. Generalized peripheral neuropathy in a dental technician exposed to methyl methacrylate monomer. Neurology 1991;41(7):1112-1116. DOI: 10.1212/wnl.41.7.1112

7. Lonnroth $\mathrm{E}-\mathrm{C}$, Wellendorf $\mathrm{H}$, Ruyter IE. Permeability of different types of medical protective gloves to acrylic monomers. Eur J Oral Sci 2003;111:440-446. DOI: 10.1034/j.1600-0722.2003.00064.x

8. Gautam R, Singh RD, Sharma VP, et al. Biocompatibility of polymethylmethacrylate resins used in dentistry. J Biomed Mater Res B Appl Biomater 2012;100B:1444-1450. DOI: 10.1002/jbm.b.32673

9. Savonius $B$, Keskinen $H$, Tuppurainen $M$, et al. Occupational respiratory disease caused by acrylates. Clin Exp Allergy 1993;23:416-424. DOI: 10.1111/j.1365-2222.1993.tb00348.x

10. Lyapina M, Dencheva M, Krasteva A, et al. Concomitant contact allergy to formaldehyde and methacrylic monomers in students of dental medicine and dental patients. Int J Occup Med Environ Health 2014;27(5):797-807. DOI: 10.2478/s13382-014-0314-4

11. Hensten-Pettersen A. Skin and mucosal reactions associated with dental materials. Eur J Oral Sci 1998;106:707-712. DOI: 10.1046/j.09098836.1998.eos10602ii08.x

12. Ortengren $\mathrm{U}$, Andreasson $\mathrm{H}$, Karlsson $\mathrm{S}$, et al. Prevalence of self-reported hand eczema and skin symptoms associated with dental materials among Swedish dentists. Eur J Oral Sci 1999;107(6):496-505. DOI: 10.1046/j.0909-8836.1999.eos107612.x

13. Ruyter IF. Release of formaldehyde from denture base polymers. Acta Odontal Scand 1980;38(1):17-27. DOI: 10.3109/00016358008997715

14. Tsuchiya $H$, Hoshino $Y$, Kato $H$, et al. Flow injection analysis of formaldehyde leached from denture-base acrylic resins. J Dent 1993;21:240-243. DOI: 10.1016/0300-5712(93)90136-e

15. Mikai M, Fujii H. Quantitative analysis of allergenic ingredients in eluate extracted from used denture base resin. J Oral Rehabil 2006;33(3):216-220. DOI: 10.1111/j.1365-2842.2005.01561.x

16. Ajay R, Suma K, SreeVarun M, et al. Evaluation of in vitro cytotoxicity of heat-cure denture base resin processed with a dual-reactive cycloaliphatic monomer. J Contemp Dent Pract 2019;20(11):1279-1285. DOI: 10.5005/jp-journals-10024-2688

17. Bayraktar G, Guvener B, Bural C, et al. Influence of polymerization method, curing process, and length of time of storage in water on the residual methyl methacrylate content in dental acrylic resins. J Biomed Mater Res B Appl Biomater 2006;76(2):340-345. DOI: 10.1002/jbm.b.30377

18. Celebi N, Yuzugullu B, Canay S, et al. Effect of polymerization methods on the residual monomer level of acrylic resin denture base polymers. Polym Adv Technol 2008;19:201-206. DOI: 10.1002/pat.996

19. Bartoloni JA, Murchison DF, Wofford DT, et al. Degree of conversion in denture base materials for varied polymerization techniques. J Oral Rehabil 2000;27(6):488-493. DOI: 10.1046/j.1365-2842.2000.00536.x

20. Azzarri MJ, Cortizo MS, Alessandrini JL. Effect of the curing conditions on the properties of an acrylic denture base resin microwave-polymerised. J Dent 2003;31(7):463-468. DOI: 10.1016/s0300-5712(03)00090-3

21. Bettencourt AF, Neves $C B$, de Almeida MS, et al. Biodegradation of acrylic based resins: a review. Dent Mater 2010;26(5):e171e180. DOI: 10.1016/j.dental.2010.01.006

22. Jorge JH, Giampaolo ET, Machado AL, et al. Cytotoxicity of denture base acrylic resins: a literature review. J Prosthet Dent 2003;90(2):190-193. DOI: 10.1016/s0022-3913(03)00349-4

23. Chaves CA, Machado AL, Vergani CE, et al. Cytotoxicity of denture base and hard chairside reline materials: a systematic review. J Prosthet Dent 2012;107(2):114-127. DOI: 10.1016/S0022-3913(12)60037-7
24. Lunder T, Rogl-Butina M. Chronic urticaria from an acrylic dentalprosthesis. Contact Dermatitis 2000;43(4):232-233. DOI: 10.1034/j.1600-0536.2000.043004223.x

25. Martin N, Bell HK, Longman LP, et al. Orofacial reaction to methacrylates in dental materials: a clinical report. J Prosthet Dent 2003;90(3):225-227. DOI: 10.1016/s0022-3913(03)00331-7

26. Kedjarune U, Charoenworaluk N, Koontongkaew S. Release of methyl methacrylate from heat-cured and autopolymerized resins: cytotoxicity testing related to residual monomer. Aust Dent J 1999;44(1):25-30. DOI: 10.1111/j.1834-7819.1999.tb00532.x

27. Harrison $A$, Huggett R. Effect of the curing cycle on residual monomer levels of acrylic resin denture base polymers.J Dent 1992;20(6):370-374. DOI: 10.1016/0300-5712(92)90031-7

28. Goiato MC, Freitas E, dos Santos D, et al. Acrylic resin cytotoxicity for denture base-Literature Review. Adv Clin Exp Med 2015;24(4):679-686.

29. Ajay R, Suma K, Ali SA. Monomer modifications of denture base acrylic resin: a systematic review and meta-analysis. J Pharm Bioallied Sci 2019;11(Suppl 2):S112-S1S125. DOI: 10.4103/JPBS.JPBS_34_19

30. Ajay R, Rakshagan V, Ganeshkumar R, et al. Synthesis and characterization of a ring-opening oxaspiro comonomer by a novel catalytic method for denture base resins. J Pharm Bioallied Sci 2021;13(Suppl 1):S521-S526. DOI: 10.4103/jpbs.JPBS_524_20

31. Ajay R, Rakshagan V, Sreevarun M, Bhuvaneshkumar D, et al. Copolymerization of ring-opening oxaspiro comonomer with denture base acrylic resin by free radical/cationic hybrid polymerization. J Pharm Bioall Sci 2021;13:S527-S531. DOI: 10.4103/jpbs.JPBS_582_20

32. Att W, Yamada M, Kojima N, et al. N-acetyl cysteine prevents suppression of oral fibroblast function on poly (methyl methacrylate) resin. Acta Biomater 2009;5:391-398. DOI: 10.1016/j.actbio.2008.07.021

33. Acosta-Torres LS, Mendieta I, Nuñez-Anita RE, et al. Cytocompatible antifungal acrylic resin containing silver nanoparticles for dentures. Int J Nanomedicine 2012;7:4777-4786. DOI: 10.2147/ijn.s32391

34. Segerström S, Sandborgh-Englund G, Ruyter El. Biological and physicochemical properties of carbon-graphite fibre-reinforced polymers intended for implant suprastructures. Eur J Oral Sci 2011;119(3):246-252. DOI: 10.1111/j.1600-0722.2011.00826.x

35. Dawlee S, Jayakrishnan A, Jayabalan M. Studies on novel radiopaque methyl methacrylate: glycidyl methacrylate based polymer for biomedical applications. J Mater Sci Mater Med 2009;20:243-250. DOI: 10.1007/s10856-008-3557-4

36. Cochis A, Fracchia L, Martinotti MG, et al. Biosurfactants prevent in vitro Candida albicans biofilm formation on resins and silicon materials for prosthetic devices. Oral Surg Oral Med Oral Pathol Oral Radiol 2012;113:755-761. DOI: 10.1016/j.00oo.2011.11.004

37. Regis RR, Della Vecchia MP, Pizzolitto AC, et al. Antimicrobial properties and cytotoxicity of an antimicrobial monomer for application in prosthodontics. J Prosthodont 2012;21(4):283-290. DOI: 10.1111/j.1532-849X.2011.00815.x

38. Ata SO, Yavuzyilmaz H. In vitro comparison of the cytotoxicity of acetal resin, heat-polymerized resin, and autopolymerized resin as denture base materials. J Biomed Mater Res B Appl Biomater 2009;91: 905-909. DOI: 10.1002/jbm.b.31473

39. Ajay R, Suma K, Sasikala R, et al. Chemical structure and physical properties of heat-cured poly(methyl methacrylate) resin processed with cycloaliphatic comonomer: an in vitro study. J Contemp Dent Pract 2020;21(3):285-290. DOI: 10.5005/jp-journals-10024-2769

40. Bailey WJ, Endo T. Synthesis of monomers that expand on polymerization. Synthesis and polymerization of 3,9dimethylene- 1,5,7,11- tetraoxaspiro[5.5] undecane. J Polym Sci Pol Chem 1976;14:1735-1741. DOI: 10.1002/macp.1975.021761011

41. Horie K, Otagawa M, Muraaoka M, et al. Calorimetric investigation of polymerization reaction. V. Crosslinked copolymerization of methyl methacrylate with ethylene dimethacrylateJ Polym Sci 1975;13: 445-486. DOI: 10.1002/POL.1975.170130217

42. Moharram MA, Abdel Nour KN, Abdel Hakeem N, et al. Effect of crosslinking agents on the molecular properties of denture baseresins. J Mater Sci 1992;27:6041-6046. DOI: 10.1007/ BF01133747 
43. Viljanen EK, Skrifvars M, Vallittu PK. Dendrimer/methyl methacrylate co-polymers: residual methyl methacrylate and degree of conversion. J Biomater Sci Polym Ed 2005;16:1219-1231. DOI: $10.1163 / 156856205774269566$

44. Schmalz G. Use of cell cultures for toxicity testing of dental materials - advantages and limitations. J Dent 1994;22(2):S6-S11. DOI: 10.1016/0300-5712(94)90032-9

45. Supervision of Medical Devices Division of the Pharmaceutical Affairs Bureau. Guideline of physical, chemical and biological study for dental materials. Japan Association for the Advancement of Medical Equipment (JAAME), Tokyo; 1997, pp. 40-41.
46. Jorge JH, Giampaolo ET, Vergani CE, et al. Biocompatibility of denture base acrylic resins evaluated in culture of L929 cells. Effect of polymerization cycle and post-polymerization treatments. Gerodontology 2007;24:52-57. DOI: 10.1111/j.1741-2 358.2007.00146.x

47. Sheridan PJ, Koha S, Ewoldsen NO, et al. Cytotoxicity of denture base resins. Int J Prosthodont 1997;10(1):73-77. DOI: 10.1016/s0022-3913(03)00349-4

48. Saravi ME, Vojdani M, Bahrani F.Evaluation of cellular toxicity of three denture base acrylic resins. J Dent (Tehran) 2012;9(4):180-188. PMCID: PMC3536452. 